\title{
MOLECULAR DETECTION OF COXIELLA BURNETII IN RAW COW'S MILK
}

\author{
A.M. Koriem ${ }^{*}$; M.F. Hussien ${ }^{* *}$; N.H. Makar ${ }^{*}$ and O.A. Sadek ${ }^{* *}$ \\ *Department of Bacteriology, Animal Health Research Institute, Assiut Provincial Lab. \\ ** Department of Food Hygiene, Animal Health Research Institute, Assiut Provincial Lab.
}

\section{ABSTRACT}

Received at: 30/3/2015

Accepted: 30/4/2015
This study aimed to detect Coxiella burnetii in raw cow's milk by using Polymerase Chain Reaction (PCR). A total of 50 raw milk samples collected from dairy farms were tested. The obtained result showed that, 7 (14\%) of the tested samples were positive for Coxiella burnetii. The public heath importance of the disease and control measures was also discussed in this study.

Key Words: Molecular detection, Coxiella burnetii, cow's milk, Assiut

\section{INTRODUCTION}

Coxiella burnetii (C. burnetii) is a strict fastidious obligate intracellular Gram-negative bacterium similar to rickettsia, which is a causative agent of important ubiquitous worldwide zoonotic infectious disease named coxiellosis or query fever (Q fever) (Raoult et al., 2005). It has a wide range of hosts including mammals such as ruminants, dogs, cats, primates, wild rodents, small mammals and nonmammals such as reptiles, amphibians, birds, fish and ticks (Parker et al., 2006; Fretz et al., 2007). Cattle, sheep and goats are the main sources of infection in humans (Angelakis and Raoult, 2010).

Coxiella burnetii is the causative agent of $\mathrm{Q}$ fever in human and animals. The ticks are considered to be the natural primary reservoirs of Coxiella burnetii and are responsible for the spread of the infection in wild animals and for transmission to domestic animals (Norlander, 2000 and Pluta et al., 2010).

The Q fever, a zoonosis that occurs worldwide (Marrie, 1990). Infected animals, especially livestock, are considered the most important source of transmission to humans (Lang, 1990). Whereas, animals in general show no clinical signs of infection except occasional abortions and other problems with reproduction such as premature birth, dead or weak offspring, and endometritis and infertility in domestic ruminants (Aitken, 1989; Maurin and Raoult, 1999 and Kazar, 2005). The infected animals usually shed the agent intermittently in milk, feces, and urine, with no outward signs of disease, and should be regarded as possible sources of human infection (Guatteo et al., 2011).
Coxiella burnetii can cause serious illness in humans. This agent is very resistant to environmental influences, and even a single infective particle can initiate an infection in the animal model (Ormsbee et al., 1978). It also, highly infectious and one to ten organisms can cause Q fever in humans (Kersh et al., 2010). Coxiella burnetii can be present in milk, urine, faeces, vaginal mucus and semen. In milk, it can be secreted for 8 days in ewes and up to 13 months in cattle (Roest et al., 2011).

Infection via inhalation of aerosolized organisms or ingestion of raw milk or fresh dairy products has been reported in humans and animals (Tissot-Dupont and Raoult, 1992). Q fever has two major manifestations in man, acute and chronic infection. Acute $Q$ fever has a variety of clinical presentations including selflimited febrile illness, pneumonia, hepatitis, meningoencephalitis and pericarditis. Rarely, it is a cause of constrictive pericarditis (Bautista-Hernandez et al., 2004). Chronic $Q$ fever is a much more serious illness and almost always means endocarditis, although infection of an aortic prosthesis or aneurysm is another manifestation of chronic Q fever (Raoult and Marrie, 1995). While still not adequately described in man, it is likely that $\mathrm{Q}$ fever during pregnancy results in chronic uterine infection with relapse during subsequent pregnancies as it does in other female mammals (Marrie, 1993 and Raoult and Stein, 1994).

The raw milk of infected cows is an important material for detecting Coxiella burnetii and diagnosing bovine coxiellosis (Stoenner, 1951). Routine diagnosis of $\mathrm{Q}$ fever is usually based on the detection of specific antibodies by complement fixation and immunofluorescence and enzyme-linked 
immunosorbent assay (ELISA) tests. Isolation of Coxiella burnetii is hazardous, difficult and timeconsuming, and requires confined biosafety level 3 laboratories due to the zoonotic nature of the microorganism (Stein and Raoult, 1992 and Field et al., 2000).

In contrast, PCR assay is a safe and useful method for detection and diagnosis of Coxiella burnetii. Moreover, at present, the polymerase chain reaction (PCR) technique has become a useful tool to detect Coxiella burnetii in biological samples (Berri et al., 2000). Several PCR-based methods have been developed targeting the isocitrate dehydrogenase gene (Nguyen and Hirai, 1999), the superoxide dismutase gene (Heinzen et al., 1999) and a transposon-like repetitive region (Hoover et al., 1992).

PCR is a highly sensitive and specific detection method that has been used previously to trace Coxiella burnetii in clinical samples (Muramatsu et al., 1996; Muramatsu et al., 1997 and Yuasa et al., 1996). A PCR performed with primers based on a repetitive, transposon like element (Trans-PCR) proved to be highly specific and sensitive, but extraction of DNA from milk samples took considerable effort and there was a high risk of contamination due to the numerous preparation steps (Willems et al., 1994).

Due to the dangerous of Coxiella burnetii for human being, the aim of this study is to detect Coxiella burnetii in raw cow's milk consumed in Assiut City, Egypt, by using PCR assay.

\section{MATERIALS and METHODS}

A total of 50 raw milk samples were collected from dairy farms in Assiut city, Egypt, under aseptic conditions. The samples were stored at $4^{\circ} \mathrm{C}$ during transportation without delay to the laboratory to be examined by Polymerase Chain Reaction (PCR) according to Berri et al. (2002); Vicari et al. (2013) and Kargar et al. (2014).

\section{Materials used for PCR:}

1.1. Reagents used for agrarose gel electrophoresis:

1.1.1. Agarose powder, Biotechnology grade (BioshopR, Candainc. lot No: OE16323). It prepared in concentration $2 \%$ in $1 \times$ TAE buffer.

1.1.2. Tris acetate EDTA (TAE) electrophoresis buffer (50×liquid concentration) (Bioshop R, Candainc. lot No: 9E11854).

The solution diluted to $1 \times$ by adding $1 \mathrm{ml}$ stock solution to $49 \mathrm{ml}$ double dist. Water to be used in the preparation of the gel or as a running buffer.

1.1.3. Ethedium bromide solution (stock solution) biotechnology grade (Bioshop ${ }^{\circledR}$ CandaInc, Lot No: 0A14667):

The stock solution was diluted by $25 \mu 1 / 200 \mathrm{ml}$ double distilled water and stored covered at $4^{\circ} \mathrm{C}$. It was used for staining of PCR products that electrophoreses on agarose gel to be visualized by UV light.

1.2. Gel loading buffer ( $6 \times$ stock solution) (Fermentas, lot No: ooo56239).

The components were dissolved in sterile double distilled water and stored covered with aluminum foil at room temperature.

1.3. DNA ladder (molecular marker): 100 bp (Fermentas, lot No: 00052518).

1.4. $5 X$ Taq master (Fermentas):

Containing polymerase enzyme, Magnesium chloride ( $\mathrm{Mg} \mathrm{Cl2})$, Deoxy nucleotide triphosphate (dNTP) and PCR grade water.

1.5. Primer sequences of Coxiella burnetii used for PCR identification system:

Application of PCR for identification of gene specified for Coxiella burnetii was performed essentially by using Trans Primers (Invitrogen, Life Technologies, Thermo Fisher Scientific Inc., UK) as shown in the following table.

\begin{tabular}{ccccc}
\hline Primer & Oligonucleotide sequence $\left(5^{\prime} \rightarrow 3^{\prime}\right)$ & $\begin{array}{c}\text { Amplicon } \\
\text { length }(\mathrm{bp})\end{array}$ & Reference \\
\cline { 1 - 2 } Trans 1 (F) & 5'TGGTATTCTTGCCGATGAC'3 & 687 & Kirkan et al. (2008) \\
\cline { 1 - 2 } Trans 2 (R) & 5'GATCGTAACTGCTTAATAAACCG'3 & & \\
\hline
\end{tabular}

\section{DNA extraction:}

One ml of raw milk was centrifuged at $2000 \mathrm{rpm}$ for 10 minutes. This procedure was performed to isolate the microbial cells in pellet of the milk samples (Berri et al., 2002). DNA was extracted from the pellet by a genomic DNA purification kit (Fermentas) according to the manufacturer's protocol. Therefore, DNA extracts were stored at $-20^{\circ} \mathrm{C}$ until they were used.

3. DNA amplification reaction:

The amplification was performed according to Kargar et al. (2014) in a thermocycler (Eppendorf -Master 
cycler personal). A total reaction volume of $50 \mu \mathrm{l}$, containing $5 \mu \mathrm{l}$ of 10 PCR buffer $(10 \mathrm{mMTris}-\mathrm{HCl}$, $\mathrm{pH} 9 \cdot 0,50 \mathrm{mM}$ potassium chloride, $0.1 \%$ Triton $\mathrm{X}$ 100), $5 \mu \mathrm{l} 25 \mathrm{mM}$ magnesium chloride, $250 \mu \mathrm{M}$ of each deoxynucleotide triphosphate, $2 \mathrm{U}$ of TaqDNA polymerase (MBI Fermentas), $1 \mu \mathrm{M}$ of each primer and $5 \mu \mathrm{l}$ of template DNA.

4. The reaction conditions of PCR:

The reaction conditions consisted of 5 cycles consisting of denaturation at $94^{\circ} \mathrm{C}$ for 30 seconds, annealing at $66^{\circ} \mathrm{C}$ (the temperature was decreased by $1^{\circ} \mathrm{C}$ between consecutive steps) for 1 minute and the extension at $72^{\circ} \mathrm{C}$ for 1 minute. Accordingly, 40 cycles consisting of denaturation at $94^{\circ} \mathrm{C}$ for 30 seconds, annealing at $61^{\circ} \mathrm{C}$ for 30 seconds and extension at $72{ }^{\circ} \mathrm{C}$ for 1 minute was carried out (Vicari et al., 2013).

The $10 \mu \mathrm{l}$ amplified products were detected by $1.5 \%$ of agarose gel electrophoresis stained with ethidiumbromide at 100 volts for 1 hour then visualized and captured on UV transilluminator. Thus, PCR products of 687 base pairs were considered indicative for identification of Coxiella burnetii.

\section{RESULTS}

Table1: Incidence of Coxiella burnetii in raw milk samples by using PCR assay.

\begin{tabular}{ccccc}
\hline Number of Samples & \multicolumn{2}{c}{ Positive Samples } & \multicolumn{2}{c}{ Negative Samples } \\
\hline 50 & No. & $\%$ & No. & $\%$ \\
\cline { 2 - 5 } & 7 & 14 & 43 & 86 \\
\hline
\end{tabular}

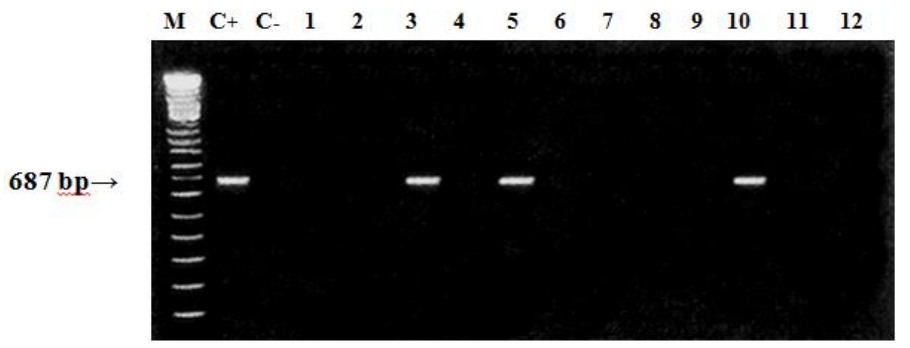

Photograph (1): Agarose gel electrophoresis of PCR of specific (Trans) primer for characterization of Coxiella burnetii in the examined milk samples.

Lane M: 100 bp ladder as molecular size DNA marker.

Lane C+: Control positive for Coxiella burnetii.

Lane C-: Control negative for Coxiella burnetii.

Lanes 3, 5 and 10: Positive milk samples for Coxiella burnetii.

Lanes 1, 2,4, 6, 7, 8, 9, 11 and 12: Negative milk samples for Coxiella burnetii.

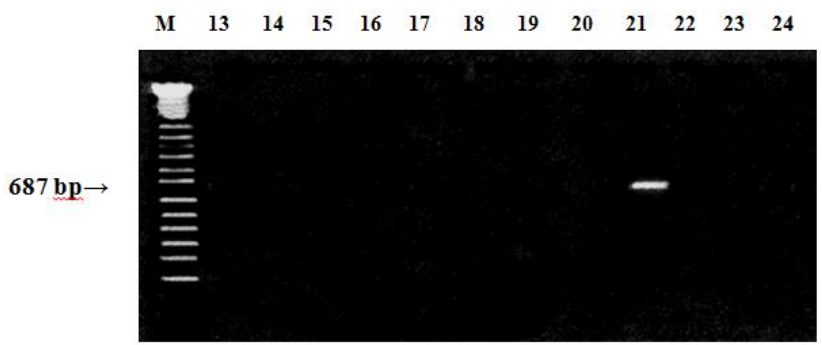

Photograph (2): Agarose gel electrophoresis of PCR of specific (Trans) primer for characterization of Coxiella burnetii in the examined milk samples.

Lane M: 100 bp ladder as molecular size DNA marker.

Lane 21: Positive milk sample for Coxiella burnetii.

Lanes 13, 14, 15, 16, 17, 18, 19, 20, 22, 23 and 24: Negative milk samples for Coxiella burnetii. 


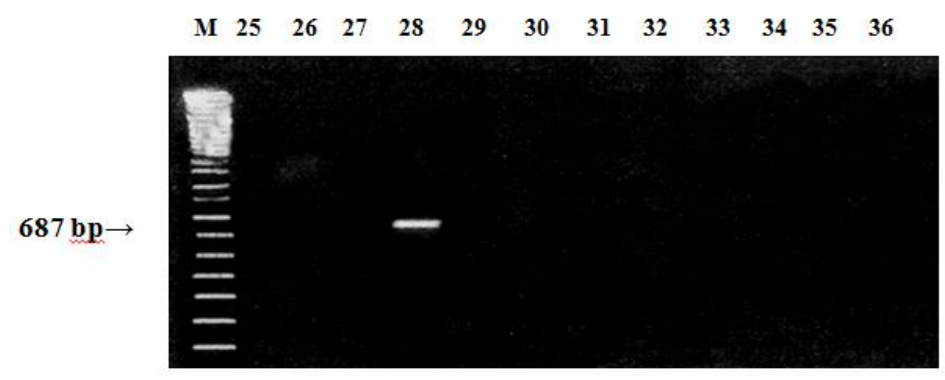

Photograph (3): Agarose gel electrophoresis of PCR of specific (Trans) primer for characterization of Coxiella burnetii in the examined milk samples.

Lane M: 100 bp ladder as molecular size DNA marker.

Lane 28: Positive milk sample for Coxiella burnetii.

Lanes 25, 26, 27, 29, 30, 31, 32, 33, 34, 35 and 36: Negative milk samples for Coxiella burnetii.

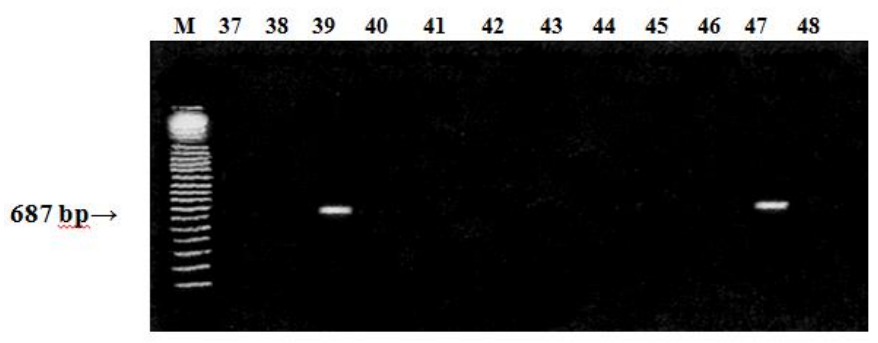

Photograph (4): Agarose gel electrophoresis of PCR of specific (Trans) primer for characterization of Coxiella burnetii in the examined milk samples.

Lane M: 100 bp ladder as molecular size DNA marker.

Lane 39 and 47: Positive milk sample for Coxiella burnetii.

Lanes 37, 38, 40, 41, 42, 43, 44, 45, 46, 48,49 and 50: Negative milk samples for Coxiella burnetii.

\section{DISCUSSION}

Routine isolation of Coxiella burnetii is very tedious and highly dangerous as presence of these bacteria in the environment, even in small numbers, poses a serious health risk to the population and its isolation required biosafety level-3 facilities (Loftis et al., 2010 and Brooke et al., 2013). Therefore, PCR assay for detection of the bacterial genome especially in milk samples is reliable but its disadvantages are due to the high cost.

The result determined in this study revealed that, out of the 50 raw cow's milk samples examined by PCR assay, 7 samples (14\%) were positive for Coxiella burnetii genome (Table 1). Nearly similar result (16.8\%) was detected by Ho et al. (1995). While, lower result $(4.7 \%)$ was estimated by Fretz et al. (2007). In contrary, higher results (33.1, 94.3, 24.4, $22,51.1,32,50,51.7$ and 27\%) were determined by (Muramatsu et al., 1997; Kim et al., 2005; Guatteo et al., 2006; Amin and Ahmed, 2009; Loftis et al., 2010; Angen et al., 2011; Muskens et al., 2011; Astobiza et al., 2012 and Petruzzelli et al., 2013), respectively.

The variance in the recovery rate may be attributed to difference in geographic distribution and to the different methods of detection. Also, variation to different seasons of the year may have an effect (Amin and Ahmed, 2009).

Adequate heat treatment of raw milk must be done before consumption to safeguard the human from being from infection as Coxiella burnetii is more heat-resistant than Mycobacterium tuberculosis, and could be isolated from pasteurized milk processed according to minimum standards (Huebner et al., 1949). Moreover, if large numbers of the $Q$ fever organism were present in raw milk, some would survive pasteurization at $143^{\circ} \mathrm{F}\left(61.7^{\circ} \mathrm{C}\right)$ for $30 \mathrm{~min}$ (Enright et al., 1957). High temperature, short-time pasteurization standards $\left(71.7^{\circ} \mathrm{C}\right.$ for 15 seconds) in the United States have been developed to inactivate Coxiella burnetii in milk (Cerf and Condron, 2006). Furthermore, UHT milk is safe for consumption as it is sterilized milk.

\section{CONCLUSION}

The result obtained in this study showed that, raw milk consumed in Assiut city, Egypt, could be representing a potential source for Coxiella burnetii infection for human being consumed such infected raw milk. Therefore, adequate heat treatment of raw 
milk before consumption must be done to safeguard the consumers from being infected by $\mathrm{Q}$ fever.

\section{REFERENCES}

Aitken, I.D. (1989): Clinical aspects and prevention of $\mathrm{Q}$ fever in animals. Eur. J. Epidemiol., 5: 420-424.

Amin, Walaa, F. and Ahmed, Silvia, O. (2009): detection of Coxiella burnetii in bovine milk samples using polymerase chain reaction. Assiut Vet. Med. J., 55 (123): 23-31.

Angelakis, E. and Raout, D. (2010): Q fever. Vet. Microbiol., 140: 297-309.

Angen, Z.; Ståhl, M.; Agerholm, J.; Christoffersen, B. and Agger, J. (2011): Dynamics of relationship between the presence of Coxiella burnetii DNA, antibodies, and intrinsic variables in cow milk and bulk tank milk from Danish dairy cattle. J. Dairy Sc., 94 (12): 5750-5759.

Astobiza, I.; Ruiz-Fons, F.; Piñero, A.; Barandika, J.; Hurtado, A. and García-Pérez, A. (2012): Estimation of Coxiella burnetii prevalence in dairy cattle in intensive systems by serological and molecular analyses of bulk-tank milk samples. J. Dairy Sc., 95 (4): 1632-163.

Bautista-Hernandez, V.; Gutierrez, F.; Ray, V.G.; Arribas, J.M.; Garcia-Puente, J.; Casinello, $N$. and Arcas, R. (2004): Constrictive pericarditis due to Coxiella burnetii. Ann. Thor. Surg., 78: 326-328.

Berri, M.; Arricau, B. and Rodolakis, A. (2002): PCR-based detection of Coxiella burnetii from clinical samples. In: Sachse K, Frey J. PCR detection of microbial pathogens (Methods in Molecular Biology). $1^{\text {st }}$ ed., Humana Press, New Jersey, USA, Pp153-161.

Berri, M.; Laroucau, K. and Rodolakis, A. (2000): The detection of Coxiella burnetii from ovine genital swabs, milk and fecal samples by the use of a single touchdown polymerase chain reaction. Vet. Microbiol., 72 (3-4): 285-293.

Brooke, R.; Kretzschmar, M.; Mutters, N. and Teunis, $F$. (2013): Human dose response relation for airborne exposure to Coxiella burnetii. BMC Infectious Diseases, 13: 488-495.

Cerf, O. and Condron, R. (2006): For Debate: Coxiella burnetii and milk pasteurization: an early application of the precautionary principle?. Epidemiol. Infect., 34: 946-951.

Enright, J.B.; Sader, W.W. and Thomas, R.C. (1957): Thermal inactivation of Coxiella burnetii and its relation to pasteurization of milk. Public Health Monograph No. 47. PHS Publication No. 517. Washington, DC: U.S. Government Printing Office.

Field, P.R.; Mitchell, J.L.; Santiago, A.; Dickeson, D.J.; Chan, S.W.; Ho, D.W.T.; Murphy, A.M.; Cuzzubbo, A.J. and Devine, P.L. (2000):
Comparison of a commercial enzyme-linked immunosorbent assay with immunofluorescence and complement fixation tests for detection of Coxiella burnetii ( $Q$ fever) immunoglobulin M. J. Clin. Microbiol., 38: 1645-1647.

Fretz, R.; Schaeren, W.; Tanner, M. and Baumgartner, A. (2007): Screening of various foodstuffs for occurrence of Coxiella burnetii in Switzerland. Int. J. Food Microbiol., 116 (3): 414-418.

Guatteo, R.; Seegers, H. and Taurel, A.F. (2011): Prevalence of Coxiella burnetii infection in domestic ruminants: A critical review. Vet. Microbiol., 149:1-16.

Guatteo, R.; Beaudeau, F.; Berri, M.; Rodolakis, A.; Joly, A. and Seegers, H. (2006): Shedding routs of Coxiella burnetii in dairy cows: implication for detection and control. Vet. Rec., 37: 827-833.

Heinzen, R.A.; Hackstadt, T. and Samule, J.E. (1999): Developmental Biology of Coxiella burnetii. Trends Microbiol., 7: 149-154.

Ho, T.; Htwe, K.K.; Yamasaki, N.; Zhamg, G.Q.; Ogawa, M.; Yamaguchi, T.; Fukushi, H. and Hirai, K. (1995): Isolation of Coxiella burnetii from dairy cattle and ticks and some characteristics of the isolates in Japan. J. Microbiol. Immunol., 39 (9): 663-671.

Hoover, T.A.; Vodkin, M.H. and Williama, J.C. (1992): A Coxiella burnetii repeated DNA element resemling bacterial insertion sequence. J. Bacteriol., 174: 5540-5548.

Huebner, R.J.; Jellison, W.L.; Beck, M.D. and Wilcox, F.P. (1949): Q fever studies in southern California. III. Effects of pasteurization on survival of Coxiella burnetii in naturally infected milk. Public Health Rep., 64: 499-511.

Kargar, M.; Rashidi, A.; Doosti, A.; Najafi, A. and Dalini, S. (2014): The sensitivity of the PCR for the detection of Coxiella burnetii in the milk samples. Zahedan J. Res. Med. Sci., 10: 29-32.

Kazar, J. (2005): Coxiella burnetii infection. Ann. NY Acad. Sci., 1063: 105-114.

Kersh, G.J.; Wolfe, T.M.; Fitzpatrick, K.K. (2010): Presence of Coxiella burnetii DNA in the environment of the United State. Appl. Environ. Microbiol., 76 (13): 4469-4475.

Kim, S.G.; Kim, E.H.; Lafferty, C.J. and Dubovi, E. (2005): Coxiella burnetii in bulk tank milk samples. United States. Emerg. Infect. Dis., 11 (4): 619-621.

Kirkan, S.; Kaya, O.; Tekbiyik, S. and Parin, U. (2008): Detection of Coxiella burnetii in Cattle by PCR. Tur. J. Vet. Ani. Sci., 32 (3): 215-220. 
Lang, G.H. (1990): Coxiellosis (Q-fever) in animals, p. 23-48. In T. J. Marrie (ed.), Q-fever: The disease. CRC Press, Boca Raton, Fla.

Loftis, A.D.; Priestley, R.A. and Massung, R.F. (2010): Detection of Coxiell aburnetii in commercially available raw milk from the United State. Food born Pathog. Dis., 7 (12): 1453-1456.

Marrie, T.J. (1990): Epidemiology of Q-fever, p. 4970. In T.J. Marrie (ed.), Q-fever: the disease. CRC Press, Boca Raton, Fla.

Marrie, T.J. (1993): Q fever in pregnancy: report of two cases. Infect. Dis. Clin. Pract., 2: 207-209.

Maurin, M. and Raoult, D. (1999): Q fever. Clin. Microbiol. Rev., 12 (4): 518-553.

Muramatsu, Y.; Maruyama, M.; Yanase, T.; Ueno, H. and Morita, C. (1996): Improved method for preparation of samples for the polymerase chain reaction for detection of Coxiella burnetii in milk using immunomagnetic separation. Vet. Microbiol., 51:179-185.

Muramatsu, Y.; Yanase, T.; Okabayashi, T.; Ueno, H. and Morita, C. (1997): Detection of Coxiella burnetii in cow's milk by PCR-Enzyme-linked immunosorbent assay combined with a novel sample preparation method. Appl. Environ. Microbiol., 63: 2142-2146.

Muskens, J.; Maanen, C. and Mars, M. (2011): Dairy cows with metritis: Coxiella burnetii test results in uterine, blood and bulk milk samples. Vet. Microbiol., 147 (1-2): 186-189.

Nguyen, S.V. and Hirai, K. (1999): Differentiation of Coxiella burnetii isolates by sequence determination and PCR-restriction fragment length polymorphism analysis of isocitrate dehydrogenase gene. FEMS Microbiol. Lett., 180: 249-254.

Norlander, L. (2000): Q fever epidemiology and pathogenesis. Microbes Infect., 2: 417-424.

Ormsbee, R.A.; Peacock, M.G.; Gerloff, R.; Tallent, G. and Wike, D. (1978): Limits of rickettsial infectivity. Infect. Immun., 19: 239-245.

Parker, N.R.; Barralet, J.H. and Bell, A.M. (2006): Q fever. Lancet, 367: 679-688.

Petruzzelli, A.; Amagliani, G.; Micci, E.; Foglini, M.; Renzo, E.; Brandi, G. and Tonucci, F. (2013):
Prevalence assessment of Coxiella burnetii and verocytotoxin-producing Escherichia coli in bovine raw milk through molecular identification. Food Control, 32 (2): 532-536.

Pluta, S.; Hartelt, K.; Oehme, R.; Mackenstedt, U. and Kimmig, P. (2010): Prevalence of Coxiella burnetii and Rickettsia spp. in ticks and rodents in southern Germany. Ticks. Tickborne Dis., 1: 145-147.

Raoult, D. and Marrie, T. (1995): Q fever. Clin. Infect. Dis., 20: 489-496.

Raoult, D. and Stein, A. (1994): Q fever during pregnancy--a risk for women, fetuses and obstetricians. N. Engl. J. Med., 4: 330-371.

Raoult, D.; Marrie, T.J. and Mege, J. (2005): Natural history and pathophysiology of Q fever. Lancet. Infect. Dis., 5: 219-226.

Roest, H.I.; Tilburg, J.J. Hoek, W. (2011): Q fever epidemic in the Netherlands: History, onset response and reflection. Epidemiol. Infect., 139 (1): 1-12.

Stein, A. and Raoult, D. (1992): Detection of Coxiella burnetii by DNA amplification using polymerase chain reaction. J. Clin. Microbiol., 30: 2462-2466.

Stoenner, H.G. (1951): Experimental Q fever in cattle-epizootiologic aspects. J. Am. Vet. Assoc., 118: 170-174.

Tissot-Dupont, H. and Raoult, D. (1992): Epidémiologie de la fièvre Q. Médecine Maladies Infectieuses, 22: 51-58.

Vicari, N.; Faccini, S. and Ricchi, M. (2013): Occurrence of Coxiella burnetii in bulk tank milk from northwestern Italy. Vet. Rec., 172 (26): 687.

Willems, H.; Thiele, D.; Frölich-Ritter, R. and Krauss, H. (1994): Detection of Coxiella burnetii in cow's milk using the polymerase chain reaction (PCR). J. Vet. Med. Ser. B, 41: 580-587.

Yuasa, Y.; Yoshiie, K.; Takasaki, T.; Yoshida, H. and Oda, H. (1996): Retrospective survey of chronic Q fever in Japan by using PCR to detect Coxiella burnetii DNA in paraffinembedded clinical samples. J. Clin. Microbiol., 34: 824-827.

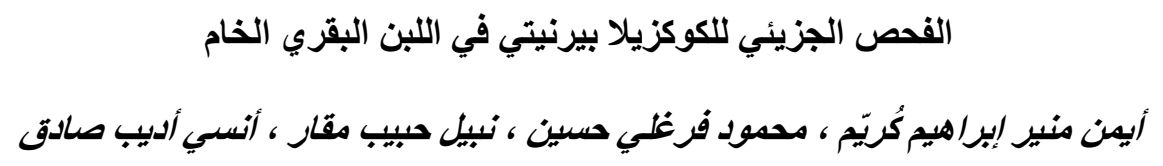

Email: Ayman_koriem@yahoo.com Assiut University web-site: www.aun.edu.eg

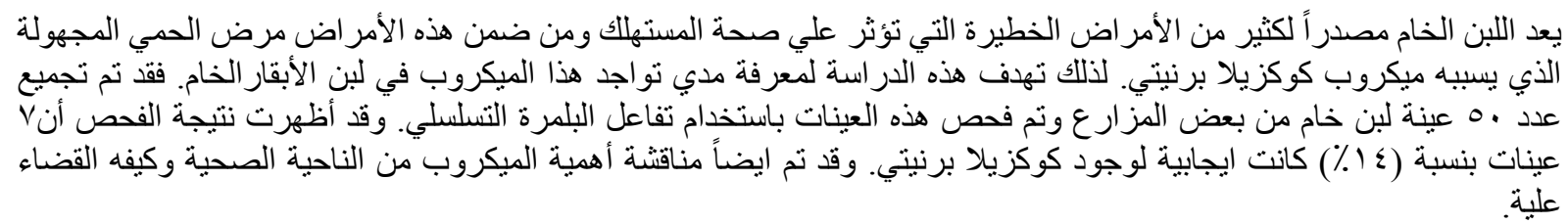

